\title{
Diazo Compounds in the Synthesis of O- and S-Containing Macroheterocycles
}

\author{
Gulnara Z. Raskildina, ${ }^{a}$ Simon S. Zlotsky, ${ }^{a}$ and Rimma M. Sultanova ${ }^{\mathrm{a}, \mathrm{b}}$ \\ ${ }^{a}$ Ufa State Petroleum Technological University, 450062 Ufa, Russia \\ ${ }^{\mathrm{b}}$ Ufa Institute of Chemistry of the Russian Academy of Sciences, 450054 Ufa, Russia \\ ${ }^{\circledR}$ Corresponding author E-mail: sultanova_rm@anrb.ru
}

The review summarizes, systematizes and analyzes literature data of the synthesis of oxygen-and sulfur-containing macroheterocyclic systems using Rh and Cu-catalyzed reactions of diazocarbonyl compounds over the last 15-20 years. The review considers the intra- and intermolecular reactions of introduction of diazocarbonyl compounds, which are used in synthesis of practically important biologically active compounds, via the $C-O$ and $C$-S bonds.

Keywords: Carbenoids, $\alpha$-diazo carbonyl compounds, O,S-macroheterocycles, cyclic acetals, C-O and C-S insertions, catalysis, ylides.

\section{Аиазосоединения в синтезе O- и S-содержащих макрогетероциклов}

\author{
Г. З. Раскильдина, ${ }^{a}$ С. С. Злотский, ${ }^{a}$ Р. М. Султанова ${ }^{a, b @ ~}$ \\ ${ }^{\text {а } У ф и м с к и и ̆ ~ г о с у д а р с т в е н н ы и ̆ ~ н е ф т я н о и ̆ ~ т е х н и ч е с к и и ̆ ~ у н и в е р с и т е т, ~} 450062$ Уфа, Россия \\ ${ }^{\text {b } У ф и м с к и и ̆ ~ и н с т и т у т ~ х и м и и ~ Р А Н, ~} 450054$ Уфа, Россия \\ ${ }^{\circledR}$ E-mail: sultanova_rm@anrb.ru
}

\begin{abstract}
В данном обзоре обобщены, систематизированы и проанализированы литературные данные по синтезу кислород- и серосодержащих макрогетерочиклических систем с использованием Rh- и Cu-катализирумых реакций диазокарбонильных соединений за последние 15-20 лет. Рассматриваются внутри- и межмолекулярные реакиии внедрения диазокарбонильных соединений по связи $C-O$ и $C-S$, используемье в синтезе практически важных биологически активных соединений.
\end{abstract}

Ключевые слова: Карбеноиды, $\alpha$-диазокарбонильные соединения, O,S-макрогетероциклы, циклические ацетали, C-O и C-S внедрение, катализ, илиды.

\section{Introduction}

Polyfunctional macroheterocycles have complexing properties, biological activity and are wide-used as catalysts, initiating agents, extractants, analytical reagents, preproducts in the synthesis of cardiovascular and psychotropic drugs, as well as antimicrobial, antiparasitic, anticancer drugs, etc. ${ }^{[1-3]}$ Besides well-known methods of obtaining macroheterocycles ${ }^{[4-7]}$ there are methods based on catalytic reactions of diazocarbonyl compounds and they are currently becoming more important. This became possible, primarily, due to the fact that the intermediate carbenes show highly electrophilic properties and readily form ylides with heteroatom compounds. The most common Lewis bases (B:) used for this purpose (ethers, sulfides, amines, and carbonyl compounds) generate oxonium, sulfonium, ammonium and carbonyl ylides, respectively (Scheme 1).

The most common reactions of catalytically generated ylides include [1,2]-shift rearrangement, or Stevens rearrangement (typical for oxonium, sulfonium, and ammonium ylides), [2,3]-sigmatropic rearrangement of allyl substituted intermediates and dipolar cycloaddition. ${ }^{[8-13]}$ 


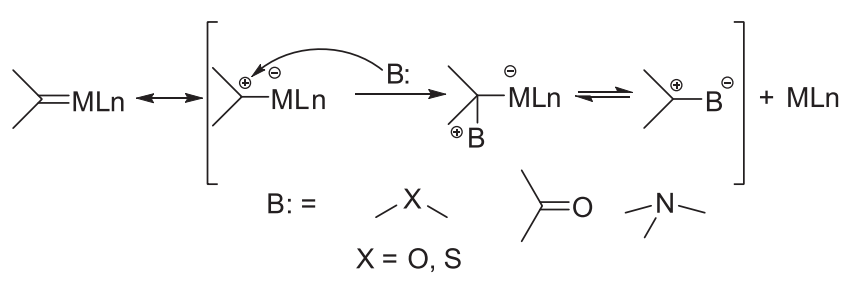

Scheme 1.

The stereochemistry of these reactions is usually determined by the structure of the original substrate, where rhodium carboxylates or homogenous complexes of copper, including enantiomeric ligands have found a wide application as catalysts of dediazotization of diazocarbonyl compounds.

\section{Intramolecular reactions}

Intramolecular catalytic reactions of diazocarbonyl compounds, such as ylide generation and insertion of the $\mathrm{C}-\mathrm{X}$ bond $(\mathrm{X}=\mathrm{N}, \mathrm{O}, \mathrm{S}, \mathrm{N})$, occur quite easily and can be used to create unique cyclic structures. ${ }^{[14,15]}$ In macroheterocycle chemistry the most successful was the reaction of the insertion of diazocarbonyl compounds by $\mathrm{C}-\mathrm{O}$ bond which allows one-stage forming of a necessary macroheterocyclic fragment.

Intramolecular generation of oxonium ylides and their subsequent stabilization give a convenient way of obtaining a variety of interesting and useful oxygen-containing heterocycles. In this aspect the conversion of cyclic acetals with a diazocarbonyl fragment in the side chain present some features of interest. For example, for bicyclic ylide 2, generated during the catalytic dediazotization of diazoketone $\mathbf{1}$ (Scheme 2) in the presence of a rhodium catalyst, nucleophilic reagents and Lewis acids, for example, $\mathrm{Ti}(\mathrm{O} i-\mathrm{Pr})_{4}$ there can be possible the parallel processes of cycle insertion and expansion. ${ }^{[16]}$ It should be noted that the adduct 4 is formed, even with the use of 0.5 equiv $\mathrm{Ti}(\mathrm{O} i-\mathrm{Pr})_{4}$ or $\mathrm{ClTi}(\mathrm{O} i-\mathrm{Pr})_{3}$. The reaction proceeds with high yields (up to $94 \%$ ) and in the presence of other electrophiles: $\alpha, \beta$-unsaturated and aliphatic aldehydes and ketones.

The highly diestereoselective tandem expansion of the cycle and process of aldol condensation in dediazotization of diazoketone $\mathbf{5}$ containing spiroacetal fragment including multicomponent reactions of tricyclooxonium ylide with alcohols, mono- or dialdehydes (Scheme 3), with the formation of alkoxioctahydro-1,4-benzodioxocine- $6(5 \mathrm{H})$ $\mathbf{6},{ }^{[17]}$ run easy enough, similarly, in the presence of tetra-isopropoxy titanium(IV).

As it has been shown ${ }^{[17]}$ the tricyclooxonium ylide and bicyclic zwitter-ion are stabilized due to delocaliza-

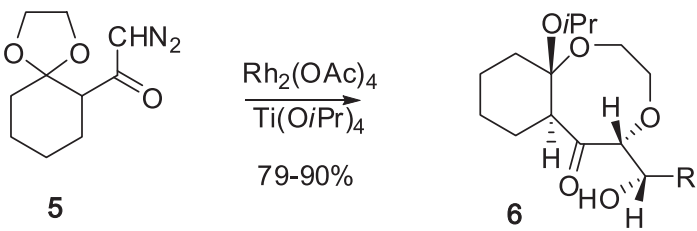

Scheme 3.

tion of the charge between the two oxygen atoms resulting to the formation of the condensed tricyclic adduct 7 in the Stevens rearrangement (Scheme 4, way a or a1). Carrying out this reaction in the presence of nucleophiles allows getting the dioxocine 8 with up to $85 \%$ yields (Scheme 4, way b) as a single diastereoisomers. The formation of possible product of intramolecular $H$-migration 9 (way c) was not observed.

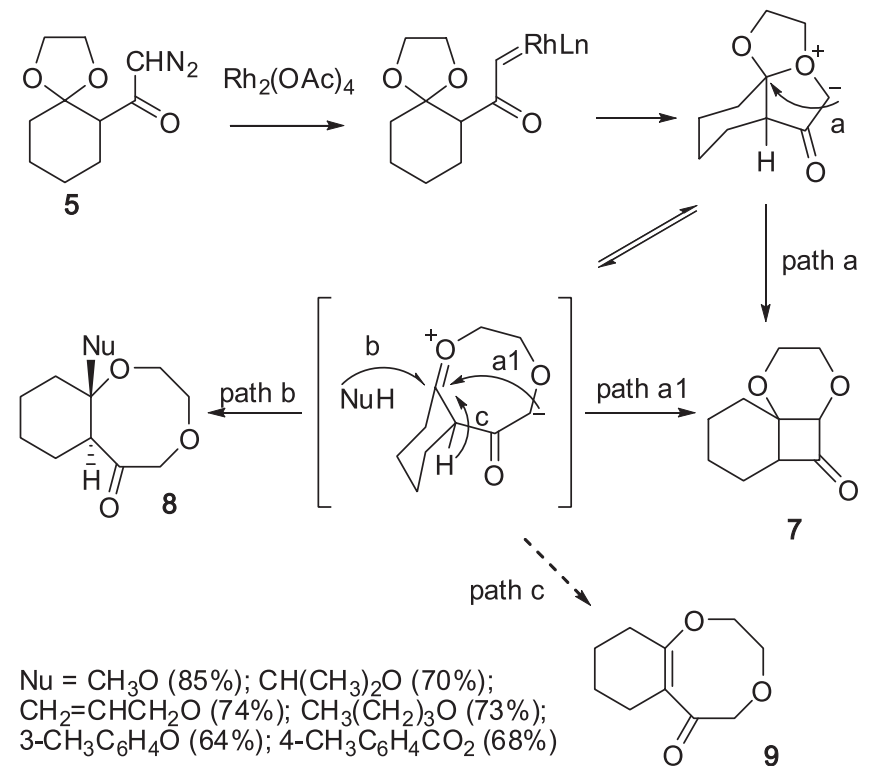

\section{Scheme 4.}

In the case of condensed bicyclic diazoketone $\mathbf{1 0}$ when using $\mathrm{Cu}(\text { hfacac) })_{2}$ (boiling in $\mathrm{CH}_{2} \mathrm{Cl}_{2}$ ) formation of ylide $\mathbf{1 2}$ is a preferred product and the product of [1,2]-shift $\mathbf{1 3}$ is formed with $80 \%$ yield (Scheme 5). It is interesting to note that the formation of tricyclic products 15, 16, and eightmembered lactones $\mathbf{1 4}$ was not observed in these conditions. [18] Moreover, the rhodium catalysts such as rhodium(II) acetate and rhodium(II) triphenylacetate were not effective in this reaction.

This methodology was used for synthesis of functional hydroazulene ring systems of phorbole type 22 (Scheme 6),

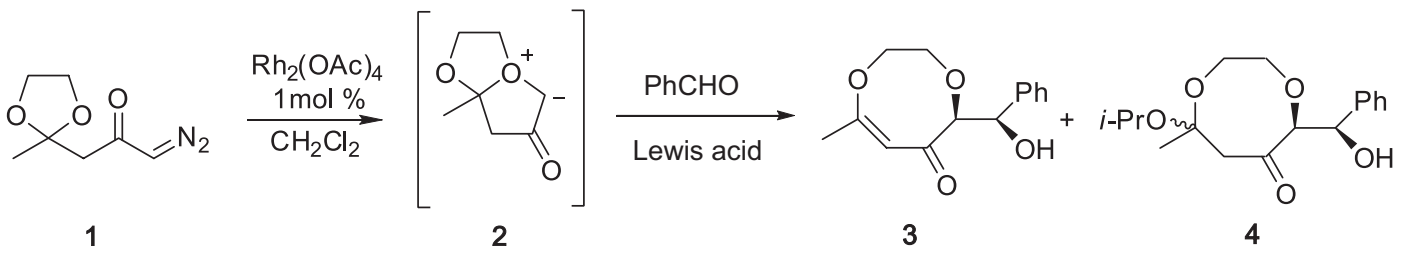

Scheme 2. 


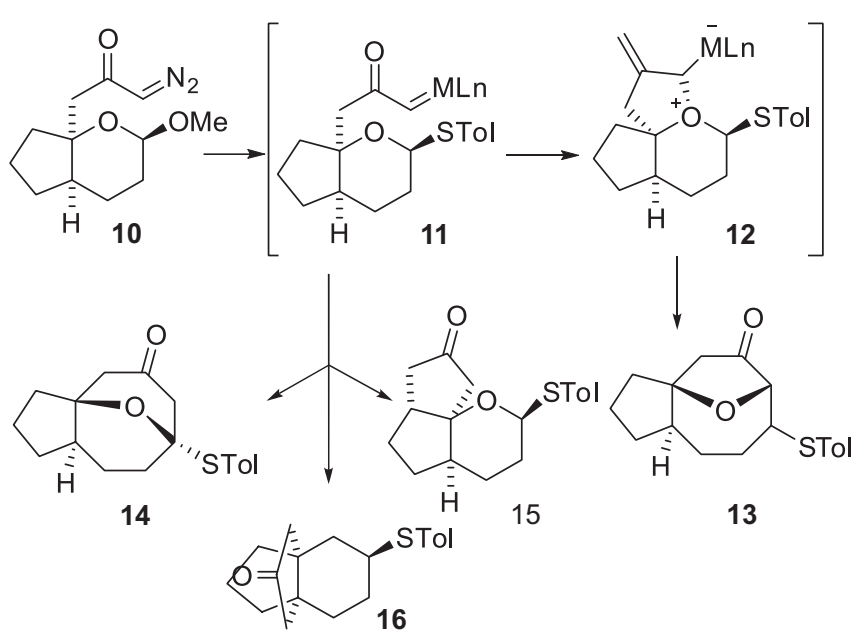

Scheme 5 .

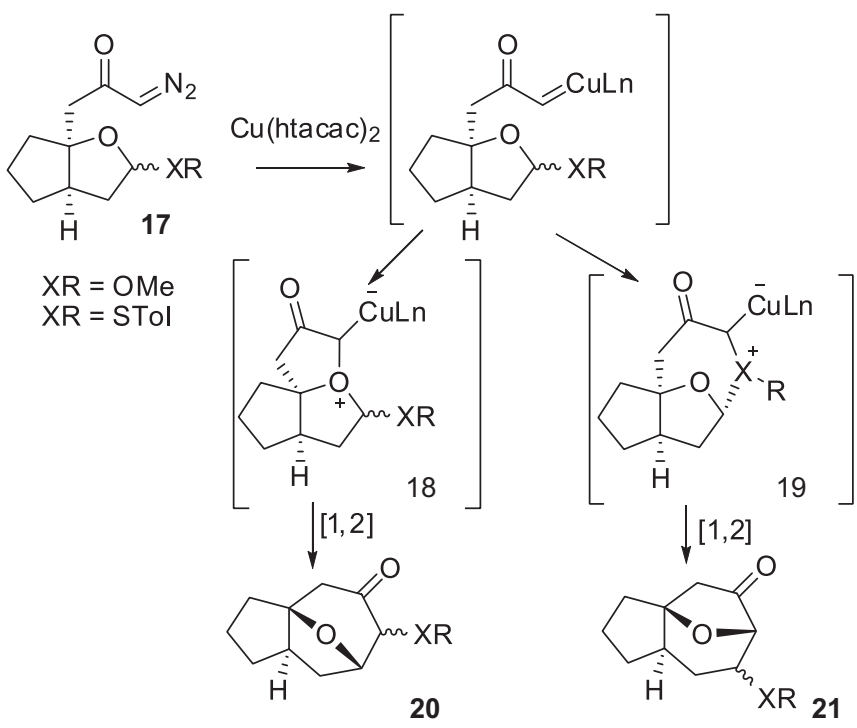

Scheme 6.

which has important biological properties, with the most notable being the ability to act as tumor promoters. The key step of this synthesis is the formation of ylides $\mathbf{1 8}$ and $\mathbf{1 9}$ as a result of catalytic decomposition of diazoketone $\mathbf{1 7}$ in the presence of $\mathrm{Cu}(\mathrm{hfacac})_{2} \cdot{ }^{[19]}$ And, apparently, the fivemembered ylide $\mathbf{1 8}$ is formed easier and, as a result, the yield of compound $\mathbf{2 0}$ reaches $68 \%$ while its isomer $\mathbf{2 1}$ is formed with a yield not exceeding $13 \%$.

The reactions of aryl substituted tetrahydropyranon diazoacetoacetates $\mathbf{2 3}$ catalyzed by rhodium(II), leading to oxabicyclo[4.2.1]nonan-4,8-diones $\mathbf{2 4}$ and $\mathbf{2 5}$ (Scheme 7) - the products of [2,3]-sigmatropic rearrange-<smiles>COCC(=N)C(=O)C[C@@H]1CC(=O)C[C@@H](/C=C/[13CH3])O1</smiles>

$$
\mid \begin{gathered}
1.0 \text { мол \% } \\
\mathrm{Rh}_{2} \mathrm{~L}_{4} \\
41-94 \%
\end{gathered}
$$

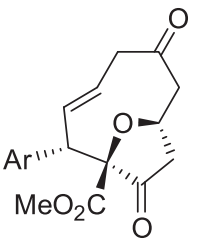

anti-24(major)

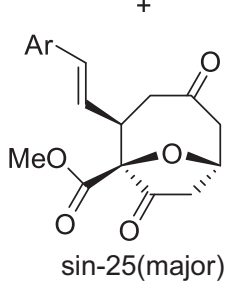

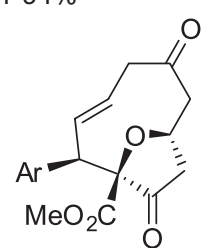

$\sin -24$ (minor)

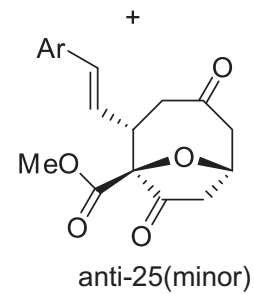

Scheme 7.

ment 24 and Stevens rearrangement 25, with preferential formation of the isomers anti-24 and $s y n-\mathbf{2 5}$, proceed much the same. The authors note that the ratio of diastereomers in all cases are almost identical and the direction of the reaction does not depend on the nature of the substituent in the para-position of the aromatic fragment in the starting diazocompounds $\mathbf{2 3}$ and counter-ion of the used rhodium catalyst $\left(\mathrm{Rh}_{2} \mathrm{~L}_{4}\right)$. Such a result is possible in the case when both processes take place via the stage of formation of the same intermediate ylide. ${ }^{[20,21]}$

The tricyclic structures containing seven-membered $O$-cycles of tigliane and daphnane classes - diterpene natural compounds have been successfully synthesized based on diazoketone 26, which was obtained from available cyclopentanone in nine stages. Boiling of the compound 26 in $\mathrm{CH}_{2} \mathrm{Cl}_{2}$ in the presence of $10 \mathrm{~mol} \% \mathrm{Cu}(\mathrm{hfacac})_{2}$ led to the formation of a single product 27 with a quantitative yield (Scheme 8). ${ }^{[22]}$
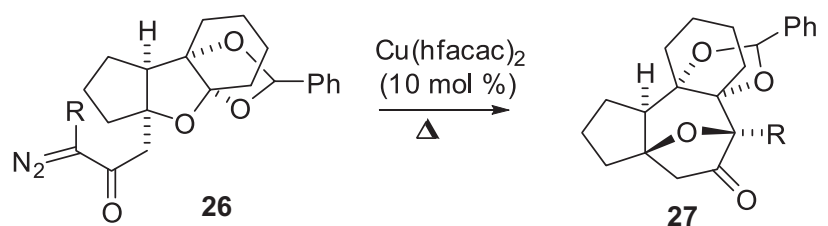

Scheme 8.

The intramolecular reaction of $\mathrm{C}-\mathrm{O}$ insertion has practical application for the synthesis of cladelliine derivatives containing the condensed average heterocycles and being diterpene metabolites of soft corals, which are combined into 
<smiles>C=C(C)C1CC[C@@H](O[Sb])[C@H](CC(=O)C=[18O])O1</smiles>

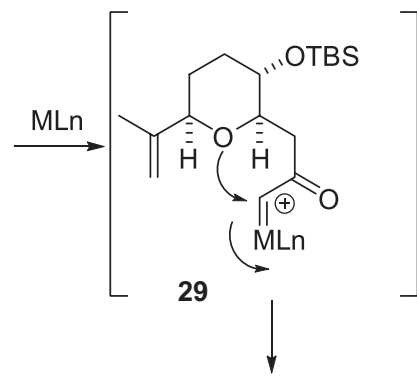

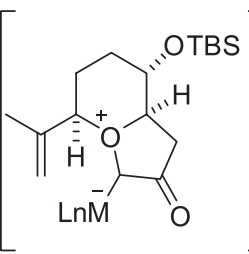

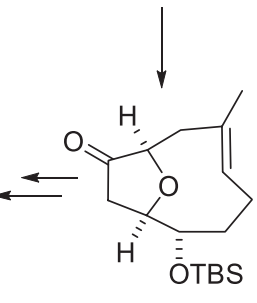

$E-30$

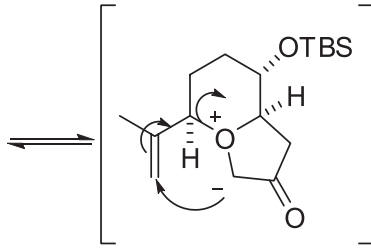

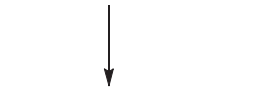

Scheme 9.

a group of eleutezides and are currently being considered as a new class of promising anticancer agents. ${ }^{[23,24]}$

The complete synthesis of 10 cladelliine derivatives consists of 6 stages, where the main step is interaction of metallocarbenoide, obtained from diazoketone $\mathbf{2 8}$, and the ester with formation of ylide-like intermediate 29, which is then rebuilt with obtaining $E$ - or $Z$-oxabicyclo[6.2.1]-5-undecen9-ones 30. The formation reaction of the bridged bicyclic ester can proceed selectively depending on the catalyst decomposition of diazoketone, and form one of the isomers as the major product (Scheme 9). ${ }^{[25]}$ Their further transformations, including Diels-Alder reaction, with the formation of tricyclic products $\mathbf{3 1}$ were used for the synthesis of intermediate products for producing of a wide range of cladelliine derivatives.

Increased nucleophility of the sulfur atom leads to the fact that the formation of sulfonium ylides as the result of intramolecular reactions of diazoketones 32, containing thioacetal fragment, proceeds easily enough. The catalysts of this reaction are mild Lewis acids - compounds of transition metals, which split easily the thioacetal fragment. As a result, we have the formation of cyclic dithiaenon 33-35 (Scheme 10) with high yields and selectivity. ${ }^{[26]}$

This approach was realized in the enantioselective formal synthesis of laurencine $\mathbf{3 8}$ (Scheme 11), natural oxacyclic ester extract from the red algae Laurencia glandulifera. ${ }^{[27]}$ It was shown that the formation of sulphonium ylides with the use of $\mathrm{Cu}(\mathrm{hfacac})_{2}$, proceeds easier than oxonium ones and selective formation of products for cycle expansion occurs due to the breaking of C-S bond of initial substituted 1,3-oxathiane 36. It is interesting to note, that the selective formation of sulfur and oxygen containing heterocycle 37 -

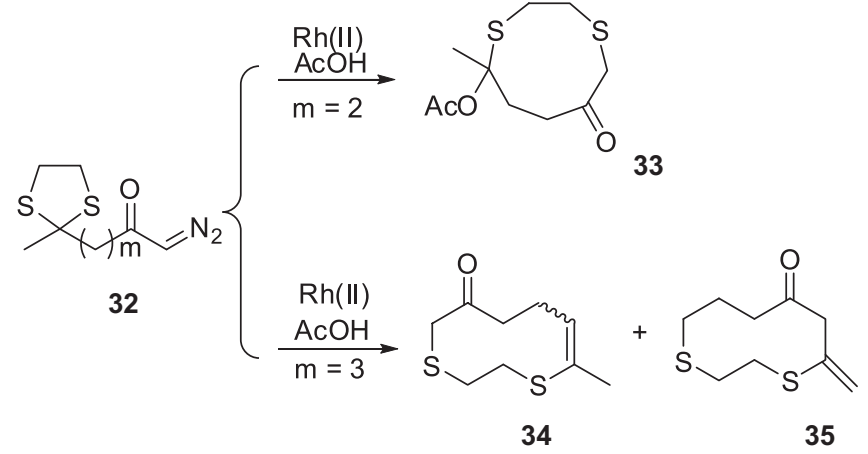

Scheme 10.

the product of [1,2]-shift of the intermediate obtaining $S$-ylide, was observed with a yield of $60 \%$ only by boiling in $\mathrm{CH}_{2} \mathrm{Cl}_{2}$ for 16 hours.

Interesting results were obtained by intramolecular macrocyclization of diazoesters of type 39 in the presence of copper- and rhodium-containing catalysts (Scheme 12). ${ }^{[28,29]}$ As it turned out that the increase of the product macrocycles yield does not require high dilution or other stringent conditions. For example, the use of rhodium containing catalysts allows carrying out selective intramolecular reaction of macrocyclization, accompanied by cyclopropanation of allyl double bond. ${ }^{[30,31]}$ It should be noted that one of the main achievements of this methodology is obtaining presqualene alcohol.

In general, as it follows from the presented results, the intramolecular cyclization of substituted diazocarbonyl compounds is a promising trend of synthesizing the multi- 
<smiles>CCOC(=O)C(=N)C(=O)C[C@H]1S[C@H](CO[Pb])O[C@@H](CC)[C@H]1OC(C)=O</smiles>

36

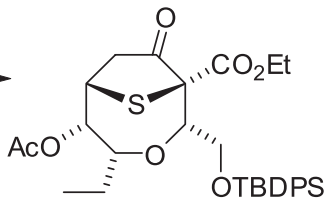

37<smiles>C#C/C=C/C[C@@H](OC(C)=O)[C@@H]1C/C=C\C[C@@H](Br)[C@H](CC#C)O1</smiles>

$(+)$-laurencine

Scheme 11.

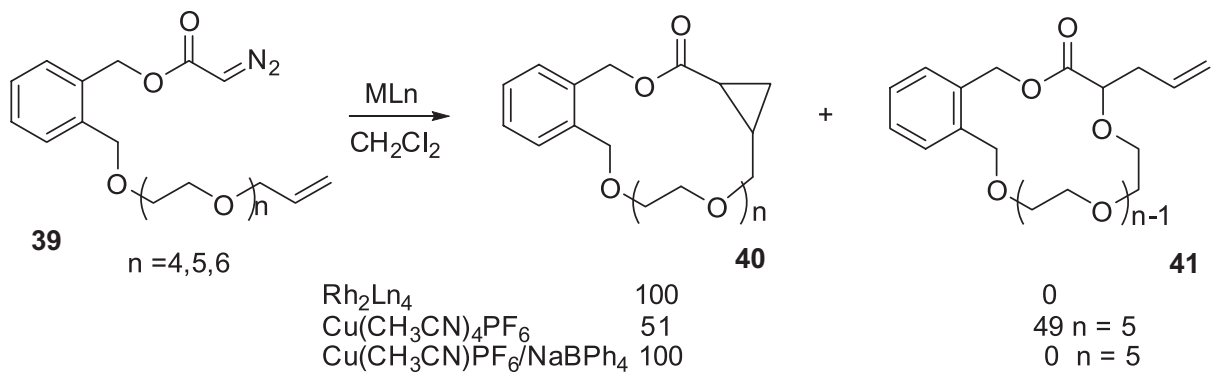

Scheme 12.

functional macro- and heterocycles.

\section{Intermolecular reactions}

The formation of macrocyclic compounds with the participation of diazocarbonyl connection is possible in intermolecular reactions also proceeding via a step of formation of corresponding ylides.

The catalytic interaction of 1,3-dioxacycloalkanes $\mathbf{4 2}$ and diazoacetic ester in the presence of transition metals complexes occurs with cycle extension and the formation

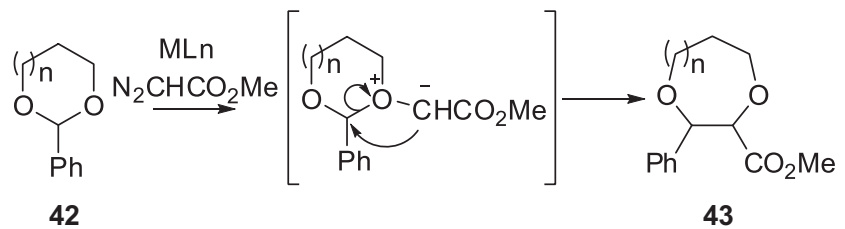

$\mathrm{n}=1,2$

$\mathrm{MLn}=\mathrm{Rh}_{2}(\mathrm{OAc})_{4}, \mathrm{Cu}(\mathrm{OTf})_{2}$

Scheme 13. of the corresponding functionally substituted 1,4-dioxacycloalkanes 43. ${ }^{[32]}$ Moreover, it is noted that only 1,3-dioxacycloalkanes containing phenyl substituent in the position 2 of the heterocycle enter into reaction (Scheme 13). This fact is in a good agreement with the mechanism of 1,2-anionic rearrangement. According to it the migrating group in transition state is a free radical, and the presence of substituents stabilizing it due to conjugation contributes to the process proceed.

The formation of products of [2,3]-sigmatropic rearrangement is observed in the interaction in $\mathrm{CH}_{2} \mathrm{Cl}_{2}$ in the presence of $\mathrm{Rh}_{2}(\mathrm{OAc})_{4}$ methyldiazoacetate with 1,3-diheterocyclopentanes $\mathbf{4 4}$ having unsaturated substituents in the 2 position of the heterocycle (Scheme 14). The attack of methoxycarbonylcarbane formed during the decomposition of methyldiazoacetate in the presence of rhodium catalyst gives intermediate ylide $\mathbf{4 5}$, and its further stabilization leads to the products of Stevens rearrangement $\mathbf{4 6}$ and $[2,3]$-sigmatropic rearrangement 47 . As it was shown in works ${ }^{[33,34]}$ the selectivity of the process is influenced by both electronic and steric factors of the heterocyclic fragment substituents.

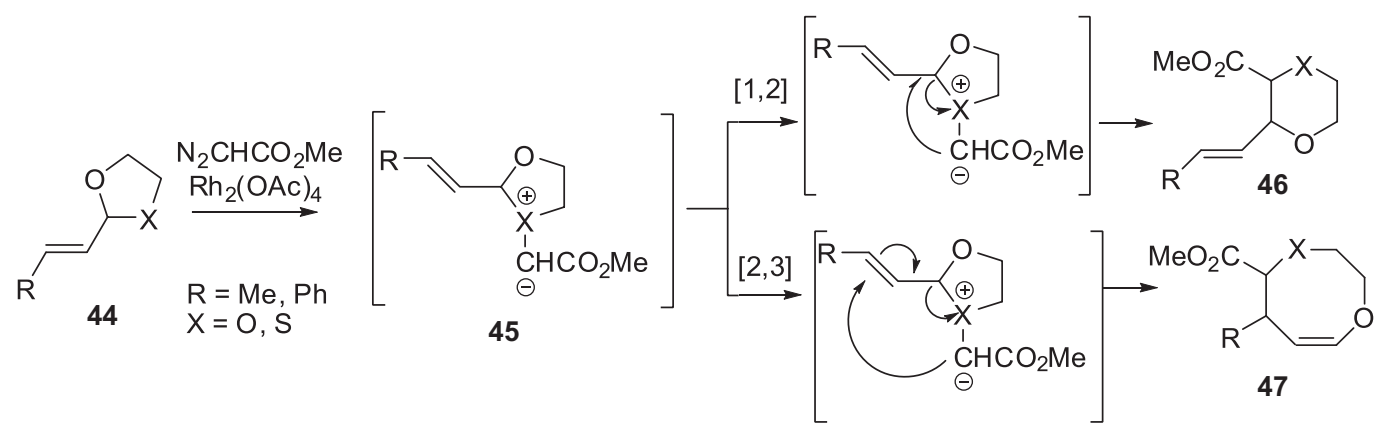




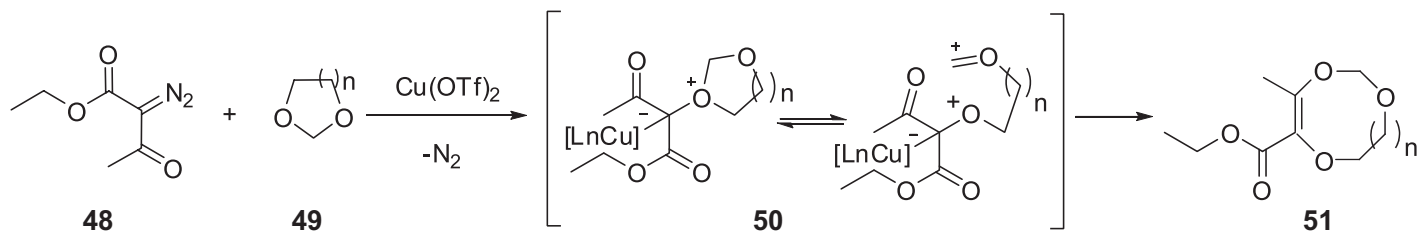

Scheme 15.

This approach was further used to obtain 8-, 9and 10 -functionally substituted polyoxa- and oxathiamacrocycles. The suitable polyoxomacrocycles $\mathbf{5 1}$ with up to $99 \%$ yields were obtained in interaction of diazoketoester 48 (Scheme 15) with 1,3-dioxacycloalkanes 49 in benzene at $80{ }^{\circ} \mathrm{C}$ in the presence of $\mathrm{Cu}(\mathrm{OTf})_{2}$. It should be noted that the insertion products of the carbenoid particle with $\mathrm{C}(2)-\mathrm{O}(3)$-bond of 1,3-doxacyclines and $\mathrm{C}-\mathrm{H}$ bond of the solvent were not found in the reaction mass. ${ }^{[35]}$

In contrast to the reaction of diazo esters with cyclic acetals containing a phenyl fragment in the 2-position of the heterocycle, which facilitates the reaction ${ }^{[32]}$ on the interaction of $\alpha$-diazo- $\beta$-ketoester with 1,3 -dioxacycloalkanes, the activating effect is produced by the substituents in the position 4 of the 1,3-dioxolane and in position 4(5) of 1,3-dioxanes, and corresponding macrocycles are formed with 45-97\% yields.

Thus, the formation of functionalized 15-membered macrocycle with $84 \%$ yield is observed in dediazotization of diazo dicarbonyl compounds $\mathbf{5 2}$ in excess of oxetane in the presence of $\mathrm{Rh}_{2}(\mathrm{OAc})_{4}$ (Scheme 16). ${ }^{[36]}$

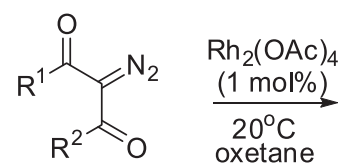

52

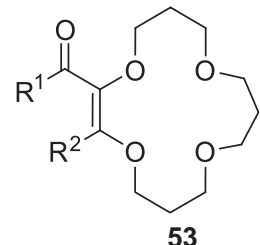

53
Scheme 16.<smiles>[R]C(=O)C([R2])=[W]</smiles><smiles>[R]C(=O)/C(OCCOCCOC([R])=C([R])OCCS)=C(\[R])OCC</smiles>
cycles with high regioselectivity. rearrangement. ${ }^{[38]}$ 59 are formed with a total yield of $97 \%$. ${ }^{[39]}$ catalyst for obtaining of functionally substituted 16 to 18 -membered macrocycles (Scheme 17), for example, it provides high yield $(75 \%)$ in obtaining of polyoxomacrocycles 55 . The reaction of $\mathrm{C}-\mathrm{O}$ insertion occurs with a high regioselectivity, and includes the condensation of two molecules of $\alpha$-diazo- $\beta$ ketoesters 54 and two molecules of 1,4-dioxane. ${ }^{[37]}$ The yield of cyclic polyesters depends on the nature of the substituent in $\alpha$-position to the keto-group, in the presence of bulky substituents such as $\mathrm{R}^{1}=\mathrm{E}$, $\mathrm{Pr}, \mathrm{Ph}, i \mathrm{Pr}$, the reaction time increases up to 12 hours. According to the proposed mechanism, the resulting $O$-ylides, having two reaction centers, react with each other, forming the final functionally substituted macro-

In recent years there is a growing interest in generating $S$-ylides, resulting from the interaction of diazo compounds with sulfides catalyzed by copper or rhodium(II) complexes. It was able to obtain stable $S$-ylides, to study the transformation of the latter and, thereby, to obtain the direct evidence of their participation in the formation of the final products. Special attention is paid to the use of chiral catalysts to obtain sulfonium ylides and their subsequent [2,3]- sigmatropic

The formation of products [2,3]-sigmatropic rearrangement was observed in the interaction of unsaturated 1,3-dithiane 56 with ethyl diazoacetate as a result of intramolecular stabilitiy of intermediate $S$-ylides (Scheme 18). The reaction proceeds easyly enough, the isomeric 9-membered thiacyclanes $\mathbf{5 7}$ and $\mathbf{5 8}$ and the intramolecular elimination product

The same rearrangement is observed in the interaction of 1,3-dithiane 60 with ethyl 2-diazo-3-oxobutyrate 48

Scheme 17.

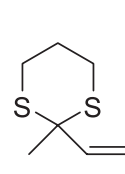

56

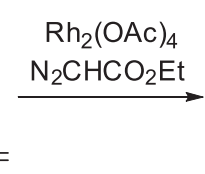<smiles>CCOC(=O)C1C/C=C(/C)SCCCS1</smiles>

57<smiles>C=CC(=C)SCCCSCC(=O)OCC</smiles>

58 
in the presence of $\mathrm{Cu}(\mathrm{OTf})_{2}$ (Scheme 19) and leads to ethyl (8Z)-9-methyl-5,6-dihydro-4H-3,7-dithio-1-oxonine-8-carboxylate 61 with $75 \%$ yield. The introduction of carbenoid particle occurs by C-S(1) bond, however, the increased nucleophilicity of the sulfur atom facilitates the reaction proceed, and oxadithionine is formed with a larger yield than trioxonine derived from 1,3-dioxane. ${ }^{[40]}$

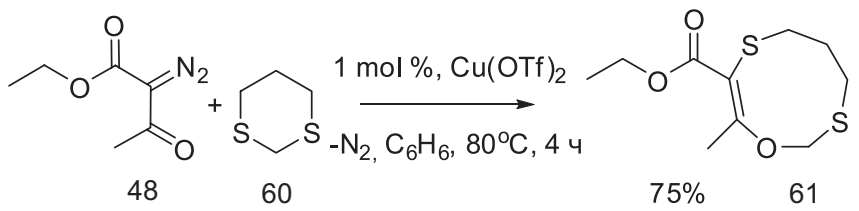

Scheme 19.

\section{Conclusion}

These data indicate that a sufficiently well-studied rearrangements of onium ylides formed by the catalytic interaction of diazo carbonyl compounds with compounds containing the bond $\mathrm{C}-\mathrm{X}(\mathrm{X}=\mathrm{C}, \mathrm{O}, \mathrm{S}, \mathrm{N})$ is one of the convenient methods to synthesize the functionally substituted macroheterocycles. Reactions of this type generally proceed with high regio- and stereoselectivity and good yields. An important feature of these reactions is their occurrence in standard conditions of dediazotization of diazo carbonyl compounds in the presence of catalysts based on copper and rhodium and without requiring a high dilution.

A wide selection of initial substrates and the possibility of varying of the nature of catalysts and reactions conditions make the research in this area of chemistry of macroheterocyclic compounds very perspective from the point of synthesizing of the new macrolides, with practically useful properties among them.

\section{References}

1. Gale P.A., Gunnlaugsson T. Chem. Soc. Rev. 2010, 39, 35953596.

2. Lee J.W., Samal S., Selvapalam N., Kim H.-J., Kim K. Acc. Chem. Res. 2003, 36, 621-630.

3. Marsault E., Peterson M.L. J. Med. Chem. 2011, 54, 19612004.

4. Martí-Centelles V., Pandey M.D., Burguete M.I., Luis S.V. Chem. Rev. 2015, 115, 8736-8834.

5. Ishmuratov G.Yu., Yakovleva M.P., Shutova M.A., Yaubasarov N.R., Muslukhov R.R., Vyrypaev E.M., Tolstikov A.G. Macroheterocycles 2014, 7, 321-324.

6. Islamova R.M., Nazarova S.V., Koifman O.I. Macroheterocycles 2011, 4, 97-105.
7. Ageeva T.A., Syrbu S.A., Koifman O.I. Macroheterocycles 2009, 2, 139-150.

8. Doyle M.P. Chem. Rev. 1986, 86, 919-939.

9. Adams J., Spero D.M. Tetrahedron 1991, 47, 1765-1808.

10. Padwa A., Krumpe K.E. Tetrahedron 1992, 48, 5385-5453.

11. Doyle M.P., McKervey M., Ye T. Modern Catalytic Methods for Organic Synthesis with Diazo Compounds. New York: Wiley, 1998. $652 \mathrm{p}$.

12. Clark J.S. In: Nitrogen, Oxygen and Sulfur Ylide Chemistry. New York: Oxford University Press, 2002. Ch. 1, p. 22-39.

13. Sweeney J.B. Chem. Soc. Rev. 2009, 38, 1027-1038.

14. Wee A.G.H. Current Organic Synthesis 2006, 3, 499-555.

15. Sultanova R.M., Khanova M.D., Zlotsky S.S. Chem. Heterocycl. Compd. 2015, 51, 775-784.

16. Sawada Y., Mori T., Oku A. J. Org. Chem. 2003, 68, 1004010045.

17. Muthusamy S., Krishnamurthi J., Suresh E. Chem. Commun. 2007, 8, 861-863.

18. Marmsäter F.P., Murphy G.K., West F.G. J. Am. Chem. Soc. 2003, 125, 14724-14725.

19. Murphy G.K., West F.G. Org. Lett. 2005, 7, 1801-1804.

20. Jaber D.M., Burgin R.N., Hepler M., Zavalij P., Doyle M.P. Chem. Commun. 2011, 47, 7623-7625.

21. Jaber D.M., Burgin R.N., Helper M., Zavalij P.Y., Doyle M.P. Org. Lett. 2012, 14, 1676-1679.

22. Stewart C., McDonald R., West F.G. Org. Lett. 2011, 13, 720723.

23. Bernardeli P., Paquette L.A. Heterocycles 1998, 49, 531-556.

24. Welford A.J., Collins I. J. Nat. Prod. 2011, 74, 2318-2328.

25. Clark J.S., Berger R., Hayes S.T., Senn H.M., Farrugia L.J., Thomas L.H., Morrison A.J., Gobbi L. J. Org. Chem. 2013, 78, 673-696.

26. Mori T., Sawada Y., Oku A. J. Org. Chem. 2000, 65, 36203625 .

27. Lin R., Cao L., West F.G. Org. Lett. 2017, 19, 552-555.

28. Doyle M.P., Hu W., Chapman B., Marnett A.B., Peterson C.S., Vitale J.P., Stanley S.A. J. Am. Chem. Soc. 2000, 122, 5718-5728.

29. Doyle M.P. J. Org. Chem. 2006, 71, 9253-9260.

30. Doyle M.P., Hu W. J. Org. Chem. 2000, 65, 8839-8847.

31. Weathers T.M., Wang Y., Doyle M.P. J. Org. Chem. 2006, 71, 8183-8189.

32. Sultanova R.M., Katashova V.R., Petrov D.A., Fatykhov A.A., Zlotsky S.S., Dokichev V.A. Russ. Chem. Bull. 2001, 50, 828830.

33. Sultanova R.M., Khanova M.D., Dokichev V.A. ARKIVOC 2009, ix, 236-247.

34. Khanova M.D., Sultanova R.M., Zlotsky S.S., Dokichev V.A. Doklady Chemistry 2007, 414, 106-108.

35. Shaihullina G.N., Sultanova R.M., Baikova I.P., Raskildina G.Z., Zlotsky S.S. Russ. Chem. Bull. 2017, 66, 164-167.

36. Rix D., Ballesteros-Garrido R., Zeghida W., Besnard C., Lacour J. Angew. Chem. Int. Ed. 2011, 50, 7308-7311.

37. Zeghida W., Besnard C., Lacour J. Angew. Chem. Int. Ed. 2010, 49, 7253-7256.

38. Padwa A., Hornbuckle S. F. Chem. Rev. 1991, 91, 263-309.

39. Doyle M.P., Griffin J.H., Chinn M.S., Van Leusen D. J. Org. Chem. 1984, 49, 1917-1925.

40. Borodin L.I., Shaihullina G.N., Sultanova R.M. Bashkir. Khim. Zh. 2016, 23(4), 3-7 (in Russ.). 